ESSAYS

\title{
I'll Be Up in the Studio Just Working on Accepting My Body and Doing Fergie Proud
}

\author{
DIVA MUKHERJI
}




\title{
I'll Be Up in the Studio Just Working on Accepting My Body and Doing Fergie Proud
}

\author{
DIVA MUKHERJI
}

\section{Monday 15/02/16 20.25}

"Four, tres, two, uno" - with will.i.am's soothing voice blasting from the speakers, mixed with Jess and my classmates cheering us on, I decide that maybe this won't be the most humiliating experience of my life. Then I remember that it's being recorded. And that WikiLeaks is a thing. Never mind.

Listening to Fergalicious, one of my ultimate self-love anthems and nervously looking at Hazel on the pole across from me, I launch into a leg whip, a classic pole move, and one that takes me back to my first taster session 7 weeks ago, when pole dancing seemed like the last thing I should be doing. But over the past few weeks, $6.55 \mathrm{pm}$ every Monday became my favourite time of the week.

Throughout the entire routine, approximately 3 minutes, I couldn't stop thinking about how I've never felt so at peace with my body (and how much I need to start going to the gym, but that was secondary). As someone who grew up loving everything about pop culture, and still do, it isn't surprising that I was reasonably confused and insecure about how I presented myself as a woman. It may be nice to hear Beyoncé telling you that you're flawless, just like her, but it's also pretty hard to forget that she is Beyoncé. Even though you know she's still just a human female, it's also easy to forget that she probably has a sizeable budget dedicated to her appearance, and uses more than just supermarket brand eyeliner. Not to mention, apparently \#nofilter \#nomakeup selfies on Instagram invariably prompts the questions - do women actually look like that? Are women supposed to look like that?

Following a ton of "body positive" blogs doesn't really help my idea of unrealistic standards of beauty when my Instagram feed is filled with seemingly perfect women. But even though I don't really have the traditional 'pole dancing' body, I'm not thinking about that as much. With my classmates cheering at my body wave, I finally don't feel like hiding my body away.

I did not expect to feel the most 'whole' while spinning around a pole. Maybe it's because of the environment in the class - the only comparison or 'aspiration' to another female I've heard was "get Beyoncé's ass!" and that definitely didn't make me feel uncomfortable. Being in a space surrounded by other women, all of whom understand exactly where you're coming from and are unconditionally cheering you on, makes everything a lot better. Sure, every time I glance at the mirrored wall in the studio I think "oh god why do I look like that", but the effect that has is hugely reduced when you also have Jess (objectively the cutest person in the world) bouncing up to you and complimenting your 'perfect' fireman spin. You know 'perfect' is an exaggeration, but that's just what you need to hear sometimes. Too often women are pitted against each other, and you can very quickly fall into the cycle of competing with other women you know - it isn't always a conscious decision, but it's just the compulsion to almost prove to everyone that you too can also do whatever another girl can, sometimes even better. But that's not what the classes feel like - it just feels like a bunch of other women being excited that you've accomplished something. The excitement feels so strangely pure as well, and the best part is that it's shared among all of you in the class, and returned to each woman individually. The happiness is infectious.

The feeling of contentment I get from class definitely makes all the 'stripper' questions worth it. Part of me acknowledges that, sure, even though I'm doing this completely for myself - and for anthropology - I'm still using my body in a way that would earn more than a few creepy winks from a certain kind of heterosexual male, and falls into line with certain forms of female objectification. Amy-Chinn (2006) found similar results while studying the business of lingerie advertising. She studies how when lingerie advertising is created in a way that perpetuates the idea of a woman as an object for male pleasure, it is acceptable. Maybe 
I have been conditioned to believe that this is empowering, when in reality I'm just a product of the patriarchy and ruining everything feminists have fought so hard for.

Is my pole dancing really that empowering if I'm motivating myself by thinking "if only Tom Hardy could see you now"? I'm making a conscious decision to use my body in this way, but I'm still using it in ways that appeal to the (mystical) male gaze - Mulvey (1989) describes the male gaze as a specific portrayal of women through the eyes of men. Mahmood (2012) states that women's desires and needs are irrevocably influenced by patriarchal ideologies. She describes it as a system of said ideals objectifying women's bodies which in turn manipulate how women begin to view their own bodies, which thereby affects how they use them. Pseudo-liberation is a strange thing: you can judge the Kardashians for spending millions on their physical appearance, but still feel like you can take over the world when you buy a great red lipstick. As much as I want to develop a meaningful relationship with my body, I also don't want to do so in a way that perpetuates hegemonic ideas of feminine sexuality.

But maybe I'm not? Yeah, okay, my ideas of female sexuality do not exist in a void where they are completely unaffected by what the media has told me what a sexual female should look and act like. But I'm also making a conscious decision. Goldman (1992) discusses the idea of commodity feminism, which outlines how women build their own image and ideals based on those that they see portrayed in the media, and their social circles. But he doesn't take into account personal autonomy - I am aware that many of the personal goals I have for my body and image are hugely influenced by who I follow on Instagram, but if I'm using these tools to feel more comfortable with my body, my interpretation of these tools become more significant.

Yes, some of my favourite pole moves are the ones that involve ridiculously dramatic and technically useless hair flips, but I'm doing it so when I look at myself in the mirror I'm like: "Hey! Okay! I can work with that!" I probably have internalized the male gaze and maybe this is all an elaborate scheme to try and make me feel better about my body, but really I'm single-handedly ruining feminism. What I want my relationship with my body to be like still exists in the realm of mass marketing that prescribes a normative image of what women's bodies should look like. But I'm still enjoying myself and feeling comfortable - shouldn't that count for something? I understand and acknowledge the history pole dancing has, and all of its associations to adult entertainment, but that is not why I'm doing it. This is for me, and only me. In the wise words of Missy Elliot, "ain't no shame ladies do your thing, just make sure you're ahead of the game".

\section{References}

Amy-Chinn, D. (2006) 'This is just for me(n) How the regulation of post-feminist lingerie advertising perpetuates woman as object.' Journal of Consumer Culture. 6(2): 155-175.

Goldman, R. (1992) Reading ads socially. London: Routledge.

Mahmood, S. (2011) Politics of piety: The Islamic revival and the feminist subject. Princeton: Princeton University Press.

Mulvey, L. (1989) 'Visual Pleasure and Narrative Cinema.' Screen. 16(3): 6-18. 